\title{
PREDICTING INTERNAL ROUGHNESS IN WATER MAINS
}

by

Thomas M. Walski, Wayne W. Sharp, F. Douglas Shields, Jr. Environmental Laboratory

DEPARTMENT OF THE ARMY

Waterways Experiment Station, Corps of Engineers

PO Box 631, Vicksburg, Mississippi 39180-0631
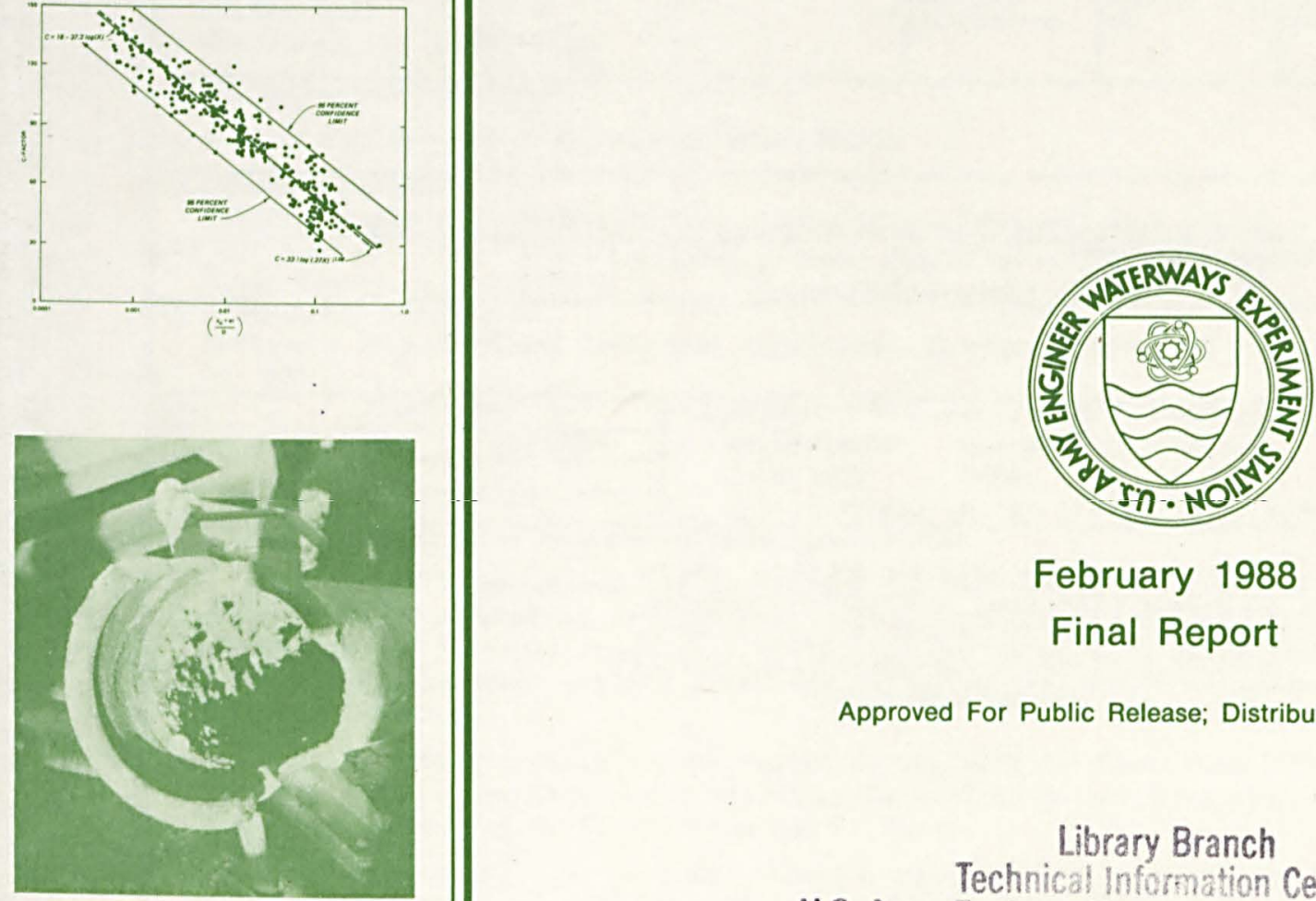

February 1988

Final Report

Approved For Public Release; Distribution Unlimited

Library Branch

Technical Information Center

U.S. Army Engineer Waternys Experiment Station Vicksburg, Mississippi 
The following two letters used as part of the number designating technical reports of research published under the Repair, Evaluation. Maintenance, and Rehabilitation (REMR) Research Program identify the problem area under which the report was prepared:

\begin{tabular}{|c|c|c|c|}
\hline & Problem Area & & Problem Area \\
\hline CS & Concrete and Steel Structures & EM & Electrical and Mechanical \\
\hline GT & Geotechnical & El & Environmental Impacts \\
\hline HY & Hydraulics & OM & Operations Management \\
\hline $\mathrm{CO}$ & Coastal & & \\
\hline
\end{tabular}

Destroy this report when no longer needed. Do not return it to the originator.

The findings in this report are not to be construed as an official

Department of the Army position unless so designated

by other authorized documents.

The contents of this report are not to be used for advertising, publication, or promotional purposes. Citation of trade names does not constitute an official endorsement or approval of the use of such commercial products.

COVER PHOTOS:

TOP - Montgomery Lock and Dam, Ohio River; freezing-thawing damage in service bridge support pier 


\section{PREFACE}

This report was prepared by the Environmental Laboratory (EL), US Army Engineer Waterways Experiment Station (WES), in fulfillment of Reimbursable Order No. CIA0-87-109 from the US Army Construction Engineering Research Laboratory (CERL). Dr. Ashok Kumar of the CERL was the primary point of contact for the work. The report was written and prepared by Dr. Thomas M. Walski, Mr. Wayne W. Sharp, and Dr. F. Douglas Shields, Jr., of the Water Resources Engineering Group (WREG), Environmental Engineering Division (EED), EL. Ms. Cheryl Lloyd of the WREG proofread the report.

The work was accomplished under the direct supervision of Dr. Shields and Dr. Paul R. Schroeder, who served as Acting Chief, WREG, and Dr. R. L. Montgomery, Chief, EED, and under the general supervision of Dr. John Keeley, Assistant Chief, EL, and Dr. John Harrison, Chief, EL.

COL Dwayne G. Lee, CE, was the Commander and Director of WES. Dr. Robert $W$. Whalin was Technical Director.

This report should be cited as follows:

Walski, Thomas M., Sharp, Wayne W., and Shields, F. Douglas, Jr. 1988. "Predicting Internal Roughness in Water Mains," Miscellaneous Paper EL-88-2, US Army Engineer Waterways Experiment Station, Vicksburg, Miss. 


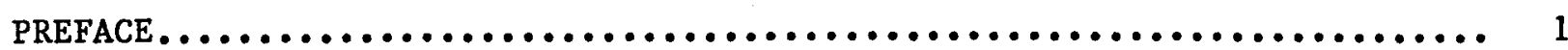

PART I : INTRODUCTION................................. 3

Background......................................... 3

Estimation of C-Factors................................ 3

PART II: SOLUTION OF HEAD LOSS EQUATIONS FOR C................. 5

Use of Hazen-Williams Equation for Rough Flow............... 5

Use of Darcy-Weisbach Equation for Head Loss................... 6

Relationship Between Roughness and C-Factor................. 6

PART III: PREDICTING GROWTH OF ROUGHNESS IN PIPES................. 9

Early observations.................................. 9

Historical Data on Roughness Growth Rate..................... 10

Formulas Based on Water Quality.......................... 11

Examination of Linear Hypothesis........................... 13

PART IV: APPLICATION OF PREDICTIVE EQUATIONS .................. 16

Procedure......................................... 16

Example Problems...................................... 18

Rate of Change of $\mathrm{C}$-Factor............................... 19

PART V: SUMMARY AND CONCLUSIONS ........................... 23

REFERENCES .............................................. 24 


\section{PART I: INTRODUCTION}

\section{Background}

1. Some measurement of the internal roughness of pipes is an important parameter entering into virtually all calculations involving the sizing and analysis of water distribution systems. In water utility practice in the United States, the Hazen-Williams C-factor is the most commonly used parameter to represent the carrying capacity (and internal roughness) of water mains.

2. In modern cement mortar lined pipes and plastic pipes, the pipe roughness changes very slowly over the life of a plpe (with the exception of waters with signiflcant scaling potential or poor removal of aluminum hydroxide flocs). However, there exist many miles of old, bare metal water mains in which the pipe roughness has changed and continues to change significantly over time.

\section{Estimation of C-Factors}

3. Knowledge of the pipe roughness (or C-factor) of In-place water mains is critical for plpe sizing calculations, and there are several ways of obtaining this information. The first is to use "typical Ifterature" values for pipe roughness. As will be shown later in this paper, the only thing "typical" about such values is that they vary widely from water system to water system.

4. A second method is to determine the internal roughness of existing mains by calculating the value of pipe roughness that w111 make a computer model of the pipe network appear to be calibrated over a wide range of conditions. Some examples of such a procedure are given by Walski (1986) and Ormsbee and Wood (1986). These methods essentially give an "effective" C-factor because many small pipes and minor losses are eliminated when the distribution system is simplified (skeletonized) to make it more workable. 
5. A third method is to actually measure the pipe roughness in the field by conducting head loss tests (Walski 1984). This method is quite expensive but gives the most credible results.

6. None of the above methods for determining C-factors, however, provide a means for extrapolating pipe roughness into the future. This paper will review pipe roughness data collected from a wide varlety of sources over many years and provide a theoretically based procedure for predicting future C-factor values. The procedure will require information on historical C-factors or water quality. 


\section{Use of Hazen-Williams Equation for Rough Flow}

7. The Hazen-Williams equation, which is traditionally used in the United States for calculating head loss and flow, is, strictly speaking, only applicable to smooth flow (1.e., flow in which roughness elements in the plpe wall do not penetrate through the laminar boundary layer). The equation becomes somewhat inaccurate for transition flow and even less accurate for completely rough flow which is usually the case in old unlined water mains. The equation can be written as:

$$
V=0.55 C D^{0.63} s^{0.54}
$$

where

$$
\begin{aligned}
& V=\text { velocity, ft/sec } \\
& C=\text { Hazen-Williams, C-factor } \\
& D=\text { diameter, ft } \\
& S=\text { hydraulic gradient, ft/ft }
\end{aligned}
$$

8. The Hazen-Williams equation, however, is still used even in rough flow because the error in predicting head loss is not significant except for long pipes with very high velocity. In most water distribution system problems, the Hazen-Williams equation is sufficiently accurate.

9. In rough flow the $C$-factor becomes a function of the velocity and can be corrected by the equation (Walski 1984) given below

$$
c=c_{0}\left(\nabla_{0} / V\right)^{0.081}
$$

where

$$
\begin{aligned}
\mathrm{C} & =\mathrm{C} \text {-factor at velocity } \mathrm{V} \\
\mathrm{C}_{\mathrm{o}} & =\text { measured C-factor at velocity } \mathrm{V}_{\mathrm{o}} \\
\mathrm{V} & =\text { actual velocity, } \mathrm{L} / \mathrm{T} \\
\mathrm{V}_{\mathrm{O}} & =\text { velocity at which } \mathrm{C} \text {-factor measured, } \mathrm{L} / \mathrm{T}
\end{aligned}
$$

The velocity at which the C-factor is measured can vary widely, but a typical value of roughly $3 \mathrm{ft} / \mathrm{sec}(0.9 \mathrm{~m} / \mathrm{sec})$ can be used for most calculations. 
Equation 2 shows that the error associated with assuming a constant but typical velocity is minor.

Use of Darcy-We1sbach Equation for Head Loss.

10. The more theoretically correct equation for head $10 s \mathrm{~s}$ is the DarcyWeisbach equation which can be solved for velocity as

$$
V=\left(\frac{2 g S D}{f}\right)^{0.5}
$$

where

$$
\begin{aligned}
& g=\text { acceleration due to gravity, } \mathrm{ft} / \mathrm{sec}^{2} \\
& \mathbf{f}=\text { Darcy-Weisbach friction factor, dimensionless }
\end{aligned}
$$

The friction factor can be calculated based on properties of the flow and the wall roughness.

\section{Relationship Between Roughness and C-Factor}

11. Because of the fact that the C-factor is a function of velocity, the initial discussion below will center on pipe roughness (e), which represents the height of equivalent sand grain roughness. When C-factors are discussed, they will be in regard to some known velocity (say $3 \mathrm{ft} / \mathrm{sec}$ $(0.9 \mathrm{~m} / \mathrm{sec}))$.

12. By solving both the Hazen-Williams and Darcy-Weisbach Equations for head loss and eliminating terms, the C-factor can be related to the DarcyWeisbach friction factor by

$$
C=\frac{17.25}{f^{0.54}(V D)^{0.081}}
$$

The friction factor, $f$, can be related to internal pipe roughness over a wide range of flows by the Colebrook-White transition equation (Colebrook 1939). However, this equation cannot be solved explicitly for $f$. Since this paper concerns pipes with significant tuberculation and scale, a simplifled form of the Colebrook-White equation, attributed to von Karman and 
Prandt 1 (von Karman 1930), that is applicable only to fully rough flow, can be used. This equation can be solved explicitly for $f$ as given below.

$$
f=[1.14-2 \log (e / D)]^{-2}
$$

where $e$ is the roughness height (same units as D). (All logarithms in this paper are base 10.) Equation 5 can be substituted into Equation 4 to give a formula relating roughness height to C-factor for a velocity of $3 \mathrm{ft} / \mathrm{sec}$ $\left(0.9 \mathrm{~m} / \mathrm{sec}\right.$ ) as shown below (neglecting the $\mathrm{D}^{0.081}$ term)

$$
C=[14.6-25.6 \log (e / D)]^{1.08}
$$

Equation 6 is used below to make conversions between C-factors and roughness height.

13. Equation 6 appears as a nearly straight line on a semi-log plot over a typical range of values for $e / D$. The exponent, 1.08 , makes the equation somewhat difficult to use and can be eliminated by determining the straight line that most closely approximates Equation 6 over the range of C-factors of Interest. This line can be given by

$$
C=18.0-37.2 \log (e / D)
$$

Equation 7 will be used in the methods presented later to predict C-factors as a function of age of pipes and water quality.

14. While the complete Colebrook-White transition formula cannot be solved explicitly for $f$ over a wide range of Reynolds numbers and pipe roughness, other formulas, most notably one by Swamee and Jain (1976) can be solved explicitly for friction factor for smooth, transition and rough flow. The formula of Swamee and Jain is given below

$$
f=\frac{0.25}{\left[\log \left(\frac{0.27 e}{D}+\frac{5.74}{N^{0.9}}\right)\right]^{2}}
$$

where $\mathrm{N}$ is the Reynolds number. 
15. Equation 8 can be inserted into Equation 4, and using a velocity of $3 \mathrm{ft} / \mathrm{sec}(0.9 \mathrm{~m} / \mathrm{sec})$ and eliminating the Reynolds number term which is negligible for rough flow, the C-factor can be given by

$$
C=33.3\left[\log (e / 3.7 D)^{2}\right]^{0.54}
$$

The above equation can be simplifled by realizing that the log term (even though it is negative) is always raised to the second power so that the absolute value of the $10 \mathrm{~g}$ can be taken and the exponents can be combined to give

$$
\mathrm{C}=33.3|\log (\mathrm{e} / 3.7 \mathrm{D})| 1.08
$$

Equations 6, 7, 9, and 10 give virtually the same value for C-factor for any value of pipe roughness greater than $0.001 \mathrm{ft}(0.305 \mathrm{~mm})$ and are reasonably close for values to $0.0001 \mathrm{ft}(0.0305 \mathrm{~mm})$. 


\section{$\underline{\text { Early Observations }}$}

16. The growth of pipe roughness with time has been observed for some time. Williams and Hazen (1920) in their original hydraulic tables give suggested values for $\mathrm{C}$-factor for each diameter pipe for various ages. They do not quantitatively describe the effect of water quality on pipe roughness. Nevertheless, their suggested values have been used as virtually "gospel" by engineers since they were first published.

17. The work of von Karman (1930), Prandt1 (1933), and Nikuradse (1932) showed that friction factors in the Darcy-Weisbach equation could be related to the plpe wall roughness and the Reynolds number of the flow. Colebrook (1938) developed an analytical relationship to describe this.

18. More importantly for this paper, Colebrook and White (1937) addressed the problem of changing pipe roughness with time. Using their data and data prepared by a Committee of the New England Water Works Association (1935), Colebrook and White advanced the hypothesis that pipe roughness grows roughly linearly with time and that the rate of growth depends most highly on the $\mathrm{pH}$ of the water. They assumed that roughness was virtually zero when the pipe was new. A slightly modifled form of their equation to predict roughness is given in Streeter (1971) as

$$
e=e_{o}+a t
$$

where

$\mathrm{e}=$ absolute roughness height, $\mathrm{L}$

$e_{0}=$ roughness height at time zero, $L$

$a=$ growth rate in roughness height, $L / T$

$t=$ time, $T$

19. The hypothesis that $e$ is a linear function of $t$ is examined in detail below. Equation 11 can now be substituted into Equations 6, 7, 9, and 10 to give a method of predicting C-factors as a function of time. This is done for Equations 7 and 10 below: 
Colebrook-White

$$
C=18.0-37.2 \log (X)
$$

Swamee-Jain

$$
C=33.3|\log (0.27 X)| 1.08
$$

where $x=\left(e_{0}+a t\right) / D$.

20. Equations 12 and 13 contain two constants, $e_{0}$, the initial roughness, and $a$, the roughness growth rate, which must be determined empirically. The inftial roughness depends on the plpe material, but a typical value of $0.0006 \mathrm{ft}(0.18 \mathrm{~mm})$ gives reasonable results for new metal pipes and is reasonably close to values reported by Lamont (1981). Methods to predict the roughness growth rate must take into account water quality. Data on the relationship of roughness growth to water quality are presented below.

\section{Historical Data on Roughness Growth Rate}

21. Colebrook and White (1937) reported values of roughness growth rate ranging from $0.000018 \mathrm{ft} / \mathrm{yr}(0.066 \mathrm{~mm} / \mathrm{yr})$ to $0.00017 \mathrm{ft} / \mathrm{yr}(0.63 \mathrm{~mm} / \mathrm{yr})$. Based on data they obtained from the New England Water Works Association (1935), they proposed the following equation to predict the growth rate, although they admitted that it was "little better than a guess."

$$
a=0.0833 \exp (1.9-0.5 \mathrm{pH})
$$

22. Another signiflcant finding of Colebrook and White was that the loss of carrying capacity was due much more to the increase in pipe roughness rather than the decrease in pipe diameter due to the space occupied by the roughness elements.

23. The roughness growth rates that could be back calculated from the tables of Williams and Hazen (1920) varled considerably depending on the diameter but generally corresponded to $0.002 \mathrm{ft} / \mathrm{yr}(0.6 \mathrm{~mm} / \mathrm{yr})$. Their values were based on a fairly limited number of observations and they noted, "In general it may be stated that rather large deviations from the Indicated rates of 
reduction in carrying capacity are found In individual cases, but that, in the experience of the authors, the varlations are about as often in one direction as in the other." They recommend fleld head loss tests when a high degree of accuracy is required.

\section{Formulas Based on Water Quality}

24. As the years went by, more investigators reported data on growth of Internal pipe roughness versus time. Lamont (1981) presented the most thorough compendium of data on pipe roughness and gave the most rational guidance on the effects of water quality on roughness growth. His approach consisted of identifying four "trends" in roughness growth and determined a linear growth rate for each trend as given in Table 1 . Lamont used the Langelier Index, which is essentially an indicator of the saturation of the water with respect to calclum carbonate, to characterize water quality. Numerical values for growth rate as compared with Langelier Index are shown in Table 1 and can be predicted by Equation 13 below

$$
a=10^{-(4.08+0.38 \mathrm{LI})} \text { for } \mathrm{LI}<0
$$

where LI is the Langelier Index. Note that Equation 15 is developed only for Langeller Indexes less than zero (i.e. corrosive water) and should not be

Table 1

Roughness Growth Rate for Varying Water Quality

\begin{tabular}{|c|c|c|c|}
\hline Trend & Name & $\begin{array}{c}\text { Growth rate } \\
\text { mm/yr } \\
\text { (ft/yr) } \\
\end{array}$ & $\begin{array}{c}\text { Langelier } \\
\text { Index } \\
\end{array}$ \\
\hline 1 & Slight attack & $\begin{array}{l}0.025 \\
0.000082\end{array}$ & 0.0 \\
\hline 2 & Moderate attack & $\begin{array}{l}0.076 \\
0.00025\end{array}$ & -1.3 \\
\hline 3 & Appreclable attack & $\begin{array}{l}0.25 \\
0.00082\end{array}$ & -2.6 \\
\hline 4 & Severe attack & $\begin{array}{l}0.76 \\
0.0025\end{array}$ & -3.9 \\
\hline
\end{tabular}


extrapolated to waters with scale forming tendencies (i.e. positive Langelier Index) or waters with other postprecipitation problems. The range of values for growth rate of roughness reported by Lamont is similar to that reported by Colebrook and White.

25. While it is possible to predict the roughness growth rate for waters with a negative Langelier Index, there is considerably less data available to predict this rate for positive Langelier Index values. Natural waters usually do not have a positive Langelier Index, and therefore, the problems with supersaturated water usually only exist in hot water lines or for utilities which soften water but do not recarbonate. Larson and Sollo (1967) describe a city in which $2 \mathrm{in}$. $(50.8 \mathrm{~mm})$ deposits of magnesium hydroxide were found in $8 \mathrm{in.}(203.2 \mathrm{~mm})$ pipes and another in which the C-factor dropped from 135 to 100 in 15 years due to calcium carbonate and magnesium hydroxide deposits. They were able to reproduce this phenomenon in stainless steel pipes in the laboratory.

26. Another problem is post precipitation of aluminum hydroxide in distribution systems where the water is treated using alum. No quantitative model is available to relate loss of carrying capacity to pH or aluminum concentration, but loss of carrying capacity has been observed by Costello (1982), Emery (1980) and Larson and Sollo (1967). Emery reported that C-factors dropped from 140 to a range of 109 to 100 over a 10- to 23-year period due to such deposits. This corresponds to a roughness growth rate of $0.00025 \mathrm{ft} / \mathrm{yr}(0.076 \mathrm{~mm} / \mathrm{yr})$.

27. A committee on Loss of Carrying Capacity of Water Mains of the California Section American Water Works Association (1962) presented data on - changes -in C-factor for the Los Angeles water system. They presented the results of over 70 tests for pipes with diameters between 4 and 16 in. (101.6 and $406.4 \mathrm{~mm}$ ). Roughness growth rates were calculated for each diameter and were found to range from 0.0020 to $0.0011 \mathrm{ft} / \mathrm{yr}(0.61$ to $0.34 \mathrm{~mm} / \mathrm{yr})$.

28. Hudson $(1966,1966,1973)$ reported the results of numerous head loss tests in nine cities. While the data were reported in terms of C-factor instead of roughness, and there was a considerable amount of scatter among the data, it was still possible to back calculate roughness growth rates, using Equation 6 for each city as shown in Table 2.

29. The above data show that most surface waters tend to be corrosive. However, the limestone well water in San Antonio proved to be much less 
Table 2

Roughness Growth Rates Calculated from Hudson's Data

\begin{tabular}{|c|c|c|}
\hline City & $\begin{array}{c}\text { Growth Rate } \\
\mathrm{mm} / \mathrm{yr} \\
(\mathrm{ft} / \mathrm{yr}) \\
\end{array}$ & Description of Water Quality \\
\hline Atlanta & $\begin{array}{l}0.61 \\
0.0020\end{array}$ & Soft river water \\
\hline Fort Worth & $\begin{array}{l}0.55 \\
0.0018\end{array}$ & $\begin{array}{l}\text { Carrying capacity lost even in concrete } \\
\text { and cement mortar lined mains }\end{array}$ \\
\hline Denver & $\begin{array}{l}0.18 \\
0.0006\end{array}$ & Mountain reservoirs \\
\hline New Orleans & $\begin{array}{l}0.16 \\
0.00052\end{array}$ & River water \\
\hline Cincinnat & $\begin{array}{l}0.14 \\
0.00043\end{array}$ & River water \\
\hline $\begin{array}{l}\text { Chicago } \\
\text { (south) }\end{array}$ & $\begin{array}{l}0.10 \\
0.00033\end{array}$ & Lake water, alum treated \\
\hline St. Paul & $\begin{array}{l}0.045 \\
0.00015\end{array}$ & Unsoftened surface water \\
\hline $\begin{array}{l}\text { Chicago } \\
\text { (north) }\end{array}$ & $\begin{array}{l}0.027 \\
0.0009\end{array}$ & Lake water, no alum \\
\hline San Antonio & $\begin{array}{l}0.015 \\
0.00005\end{array}$ & Wells in Iimestone \\
\hline
\end{tabular}

corrosive because it is near saturation with respect to calcium carbonate. Unfortunately, data on the $\mathrm{pH}$, calcfum, and alkalinity of the waters in the above table were not avallable so a quantitative method to predict growth rate as a function of water quality could not be developed. The higher growth rate for the Chicago south treatment plant is attributed to postprecipitation of aluminum hydroxide.

\section{Examination of Linear Hypothesis}

30. If sequential measurements of C-factor spanning several years are avallable for the plpe sizes and water source of interest, and if water quality has been fairly unchanged over this period of record, then the engineer 
can predict C-factors as a function of pipe age using Equation 12 or 13. The likely error inherent in such an approach is probably acceptable if the hypothesis that pipe roughness is a Ilnear function of pipe age.

31. The predictive equations for $C$ (Equations 12 and 13) are based on the hypothesis that pipe roughness, $e$, is a linear function of pipe age, $t$. This hypothesis was examined using all avallable data. The data set used consisted of sequential measurements of $C$ for pipes of known diameter and age. Some 319 data points from seven utilities plus values from Williams and Hazen (1920) and average values from Lamont (1981) were used. First, all C-factors were converted to pipe roughness values (e) using Equation 16. Then, for each utility, pipe roughness growth rates (a) were determined for each pipe diameter by linear regression. The values of $e$ computed with Equation 16 were input to the regression as dependent varlable values, and pipe ages $(t)$ were the dependent variable values. The a values determined from regression were then combined with published or measured values of $e_{0}$ and the known values of $D$ and $t$ to compute $X$.

32. The amount of scatter present in the entire data set, and thus the validity of the linear hypothesis, was examined by plotting $C$ versus $\log (\mathrm{X})$ as shown in Figure 1. Figure 1 indicates that a linear function of $t$ is a good predictor of pipe roughness and therefore Equations 12 or 13 may be used to predict C-factors as a function of pipe age. The 95-percent confidence interval about the regression line is also shown in Figure 1. Predicted $C$-factors are within an interval of \pm 15 of observed values with 95-percent confidence. The coefficlent of determination for both equations is 0.87 , which means that the equations describe 87 percent of the variation in $C$. This is especially good considering the fact that the data were collected by a wide variety of investigators for a wide range of conditions. For example, different investigators use different methods for determining minor head losses.

33. In addition to the fact that all of the observations fall reasonably close to both predicted curves, the two equations (12 and 13) give nearly equal results over the range of $C$ normally encountered. Therefore, either can be used, depending on the preference of the engineer. Examples of their use follow. 


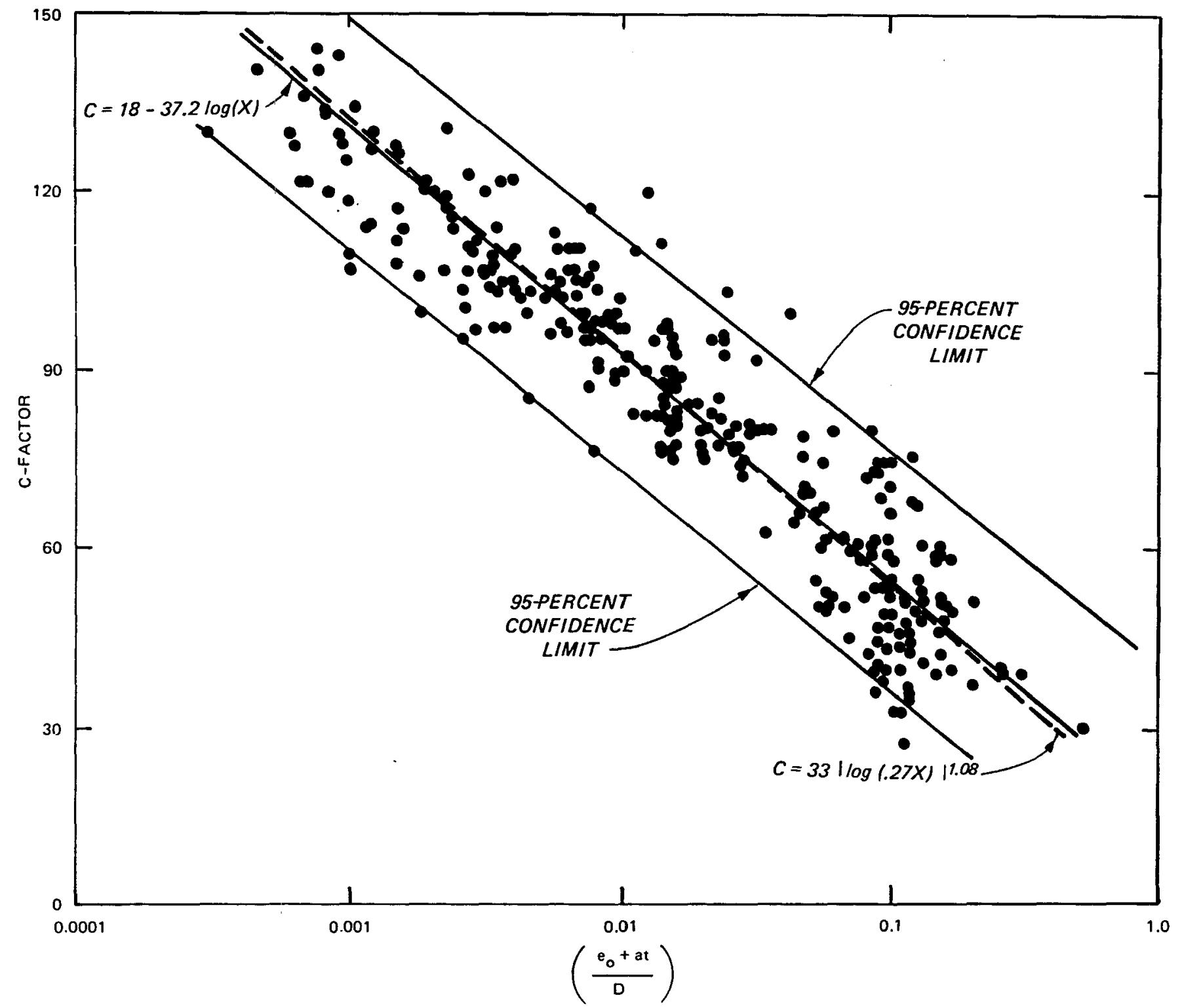

Figure 1. C-factor versus $\log (\mathrm{X})$ 


\section{$\underline{\text { Procedure }}$}

34. To apply the predictive equation to a water system, the engineer needs to first determine the growth rate of roughness. This can be done in two ways. First, if $\mathrm{C}$-factor and pipe age data are available, the engineer can plot pipe age versus roughness (e). Roughness (e) can be calculated from C-factor by solving Equation 6 or 10 for $e$ :

$$
\begin{aligned}
& e=D\left(10^{[(18-C) / 37.2])}\right. \\
& e=3.7\left(D 10^{-}\left[\left(C^{0.926}\right) / 25.7\right]\right)
\end{aligned}
$$

The slope of the $e$ versus $t$ plot will be the growth rate which can be used for predicting future C-factors. The intercept with the vertical axis gives an indication of inftial pipe roughness. However, since new pipe C-factors usually are not measured, since there is some error in C-factor measurements, and since the predictive equations are not very accurate for roughness approaching zero, the estimates of initial roughness may appear unreasonable in some cases (e.g. negative). In such cases, the engineer should use typical inftial roughness values of approximately $0.0006 \mathrm{ft}(0.18 \mathrm{~mm})$. In any case, the value of initial roughness will usually have very little effect on C-factors after the first few years of a pipe's life.

35. If the transformed data do not fall on a straight line with reasonable error, the engineer must consider why this has occurred. The usual explanation is that water quality has changed during the life of some of the pipes. The engineer must then try to determine the aging rate given the current water quality since that water quality will influence future changes in C-factor.

36. If historical C-factor values are not avallable or water quality is expected to change in the future, then the engIneer must predict roughness growth based on water quality. Equation 15 should be used for this purpose since the Langelier Index is based on more than simply $\mathrm{pH}$, as given in Equation 14. Corrosion Inhibitors will also have an effect on growth rate. 
37. Once the roughness growth rate is known, the C-factor in a given year can be predicted using Equations 12 and 13, knowing the age of the pipe for that year. This is an acceptable procedure if the precise age of installation of each pipe segment is known. Determining the year laid for each pipe segment can be a fairly tedious process and is one that is currently not required in most pipe network models. An alternative procedure is to extrapolate the $\mathrm{C}$-factor given the current value. The current value can be determined from field tests or the value needed to calibrate a pipe network model as discussed earlier.

38. To modify the predictive equations so that the year laid need not be known, it is necessary to first substitute for pipe age in the equations as shown below

$$
t=T-T_{0}
$$

where

$$
\begin{aligned}
T & =\text { year of interest (e.g. 1995) } \\
T_{0} & =\text { year of Installation }
\end{aligned}
$$

It is possible to reorganize Equations 12 and 13 to eliminate $T_{0}$, which results in an equation to predict C-factor in any year $T$, given the C-factor in some other year, $\mathrm{T}_{1}$ :

$$
\begin{aligned}
& C=18.0-37.2 \log \left[\frac{a\left(T-T_{1}\right)+D 10^{\left(18-C_{1}\right) / 37.2}}{D}\right] \\
& C=33.3\left\{\log \left[\frac{0.27 a\left(T-T_{1}\right)+D 10^{-C_{1}^{0.926 / 25.7}}}{D}\right] \mid\right\}^{1.08}
\end{aligned}
$$

where

$$
\begin{aligned}
& \mathrm{C}_{1}=\text {-factor in year } \mathrm{T}_{1} \text { (known) } \\
& \mathrm{T}_{1}=\text { year in which } \mathrm{C} \text {-factor is known }
\end{aligned}
$$$$
\mathrm{T}=\text { year in which } \mathrm{C} \text {-factor is predicted }
$$

39. The above equations can be easily incorporated into computer models of pipe networks so that an engineer can simulate future system behavior. 
40. Two example problems to illustrate the predictive equations are presented below. The first covers the case in which no C-factor data are avallable, but the year the pipe was lafd is known. The second covers the case in which there are some historical $\mathrm{C}$-factor data.

Example 1

41. It is necessary to predict the C-factors in 1995 for the pipes described in the first three columns of Table 3 . The pipes are unlined cast Iron and Langelier Index for the water 1s -1.5 . Determine C-factors for several Individual plpes plus plots of C-factor versus age for $6,12,24$ and 36 in. $(152.4,304.8,635.0$ and $914.4 \mathrm{~mm})$ pipes.

Table 3

Data for Example 1

\begin{tabular}{cccc}
\hline P1pe & $\begin{array}{c}\text { Diameter } \\
(\mathrm{ft})\end{array}$ & $\frac{\text { Year La1d }}{1925}$ & $\frac{\text { C in 1995 }}{1}$ \\
\cline { 2 - 3 } 2 & 0.5 & 1905 & 68 \\
3 & 0.5 & 1940 & 64 \\
4 & 0.5 & 1925 & 72 \\
\hline
\end{tabular}

42. The rate of aging can be estimated from Equation 15 as

$$
a=10^{-[4.08+0.38(-1.5)]}=0.00031 \mathrm{ft} / \mathrm{yr}(0.095 \mathrm{~mm} / \mathrm{yr})
$$

The age of each pipe in 1995 can be determined by subtracting the year laid from 1995. Then, using an Initial roughness of $0.0006 \mathrm{ft}(0.18 \mathrm{~mm})$, EquatIon 12 can be used to generate the C-factor in 1995 as

$$
C=18.0-37.2\left\{\log \left[0.0006+0.00031\left(1995-T_{0}\right)\right] / D\right\}
$$

A plot of C-factors versus age for several diameter pipes is shown in Figure 2. Note that C-factor decreases more rapidly in small diameter pipes. 


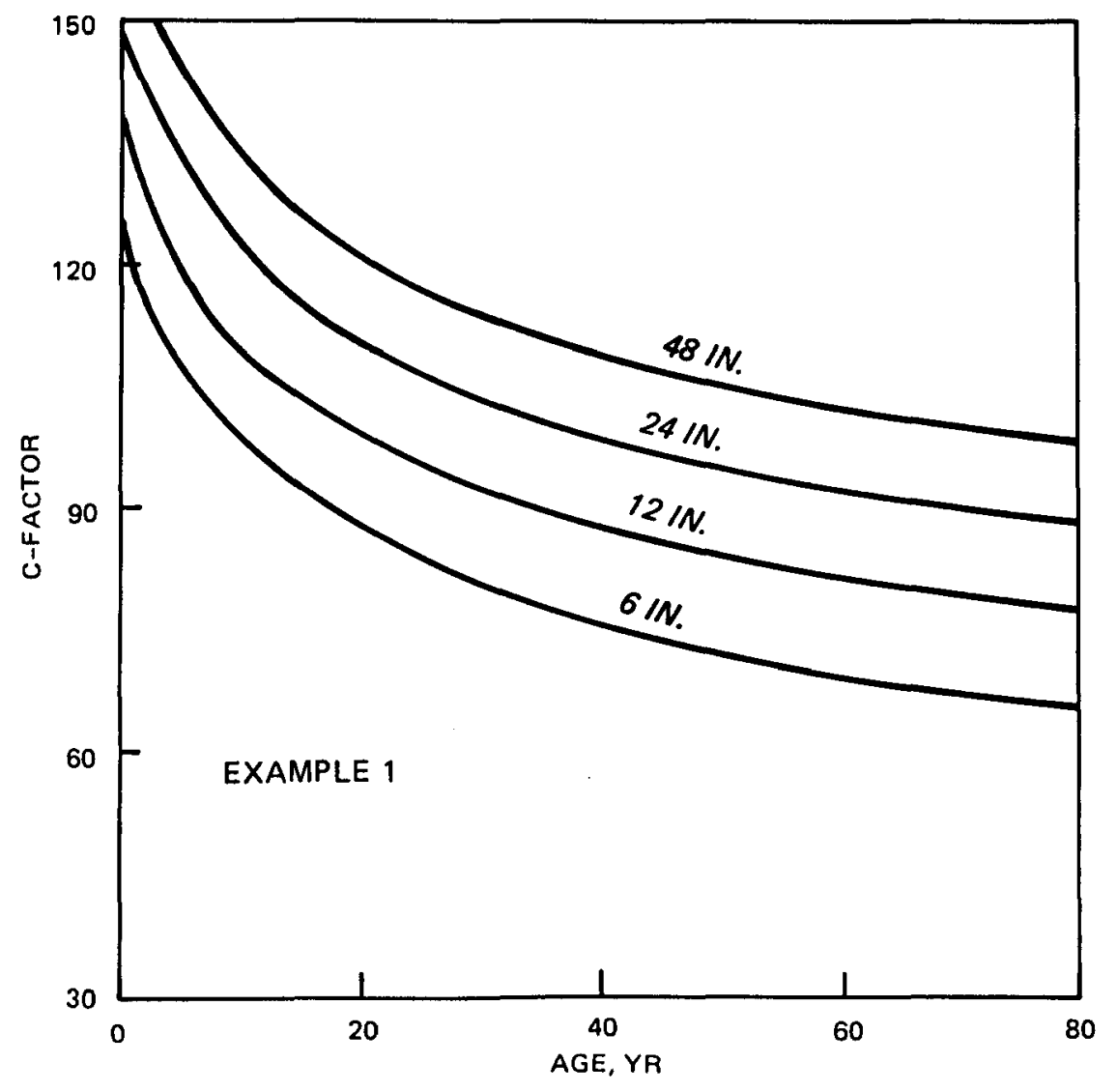

Figure 2. C-factor versus age

\section{Example 2}

43. In this problem, several C-factor tests were conducted and the results are shown in the first three columns of Table 4. The data were then transformed as shown in Equation 17, and the results are shown in Figure 3. The roughness growth rate was found to be $0.0019 \mathrm{ft} / \mathrm{yr}(0.58 \mathrm{~mm} / \mathrm{yr})$ using $1 \mathrm{in}-$ ear regression. Equation 20 was then used to predict the C-factors in 2005:

$$
C=33.3\left\{\left|\log \left[\frac{0.0103+D 10^{-\left(C_{1}^{0.926} / 25.7\right)}}{D}\right]\right|\right\}^{1.08}
$$

\section{Rate of Change of C-Factor}

44. While pipe roughness increases linearly with time, C-factors initially decrease rapidly and then change more gradually as shown in Figure 2. 


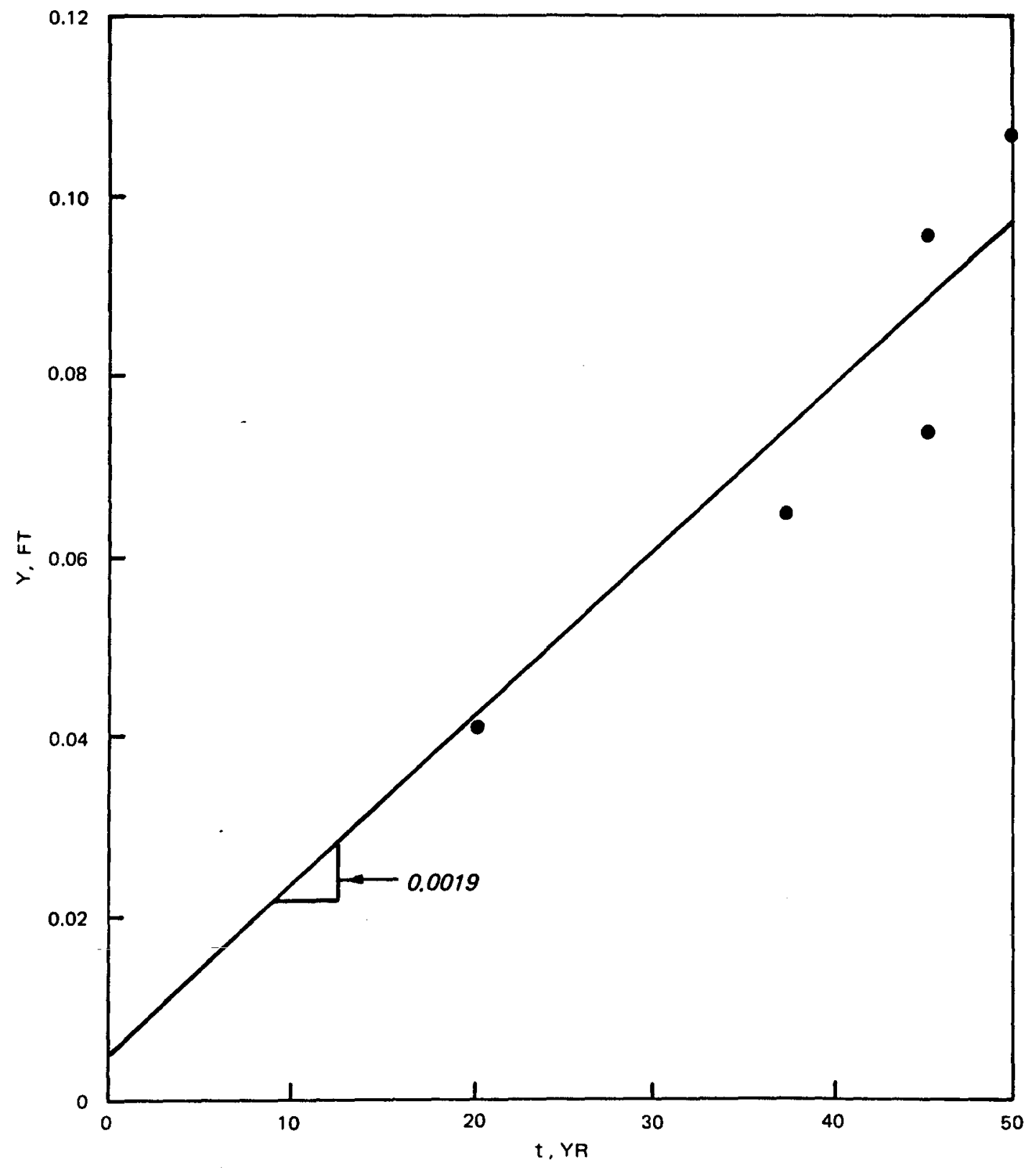

Figure 3. Growth rate versus time for Example 2 
Table 4

Data for Example 2

\begin{tabular}{|c|c|c|c|c|c|}
\hline Pipe & $\begin{array}{c}\begin{array}{c}\text { Diameter } \\
(\mathrm{ft})\end{array} \\
\end{array}$ & $\begin{array}{l}\text { C-factor } \\
\text { in } 1985\end{array}$ & $\begin{array}{l}\text { Age in } \\
1985 \\
\end{array}$ & $\begin{array}{c}e \\
(f t)\end{array}$ & $\begin{array}{l}\text { C factor } \\
\text { 1n } 2005\end{array}$ \\
\hline 1 & 2.0 & 80 & 20 & 0.041 & 69 \\
\hline 2 & 1.0 & 61 & 35 & 0.065 & 54 \\
\hline 3 & 1.0 & 55 & 45 & 0.095 & 50 \\
\hline 4 & 0.5 & 48 & 45 & 0.073 & 41 \\
\hline 5. & 0.5 & 42 & 50 & 0.107 & 37 \\
\hline
\end{tabular}

This explains why results of pipe cleaning jobs, when not accompanied by cement mortar lining or a change in water quality, are usually short lived as described by Dutting (1968) and Frank and Perkins (1955). To quantify this effect, it is possible to take the derivative of Equation 12 with respect to time. This gives the rate of change in C-factor with time.

$$
\frac{d C}{d t}=\frac{-16.1}{\left.\left[\left(e_{0} / a\right)+t\right)\right]}
$$

The absolute value of the right side of Equation 21 is plotted in Figure 4 for roughness growth rates, $a$, of 0.001 and $0.0001 \mathrm{ft} / \mathrm{yr}(0.305$ and $0.0305 \mathrm{~mm} / \mathrm{yr}$ ). Figure 4 shows that the C-factor drops off initially, decreases rapidly and then changes very slowly. 


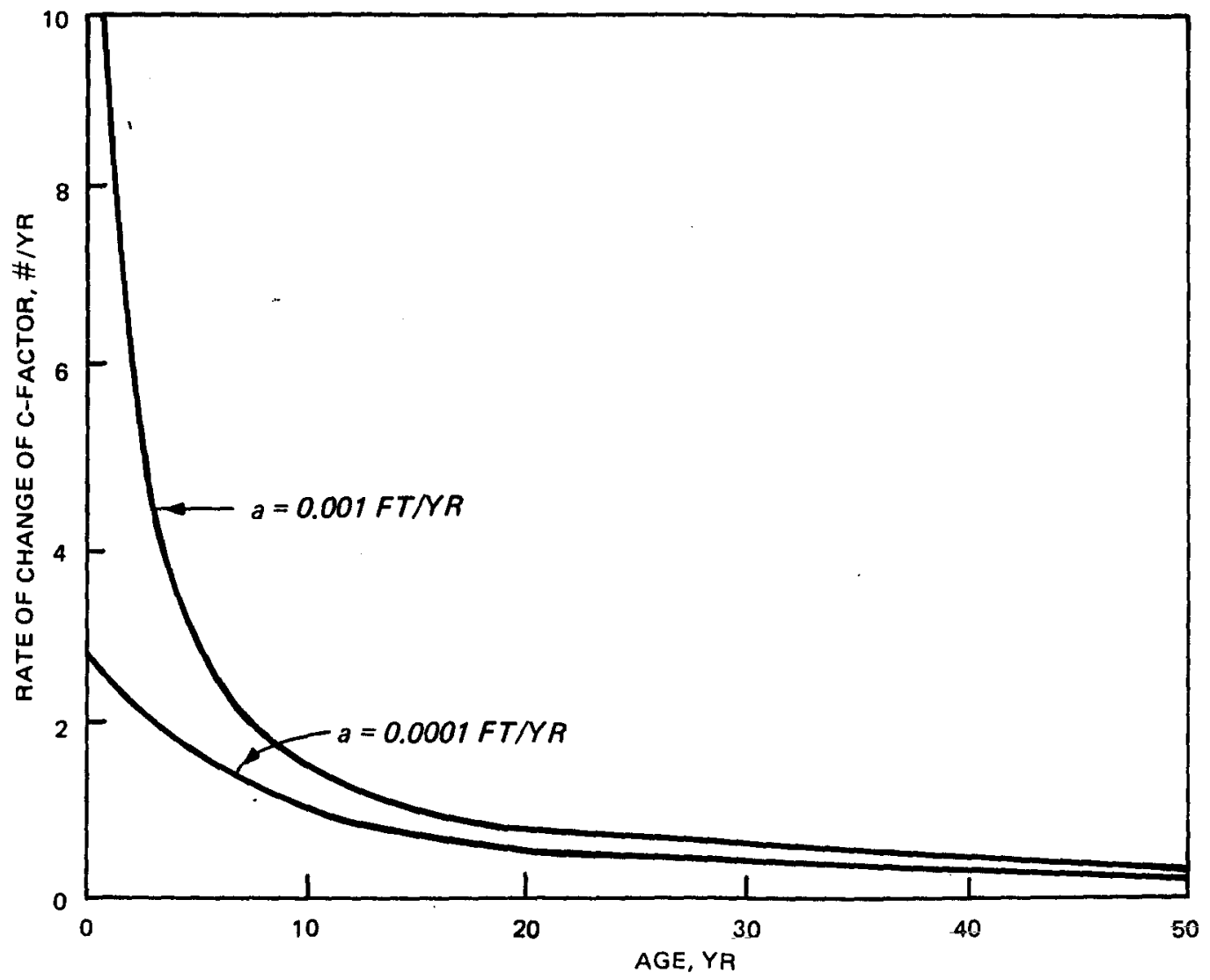

Figure 4. Rate of changes of C-factor versus time 


\section{PART V: SUMMARY AND CONCLUSIONS}

45. The equations presented in this paper provide an easy-to-use but accurate method for predicting C-factors in unlined metal pipes. The data substantiate the claim of Colebrook and White (1937) that roughness height in such pipes grows roughly linearly over time.

46. The equations presented depend most heavily on the parameter, $a$, that describes the rate of growth of roughness over time and depends on the quality of the water with respect to corrosion or precipitation. This parameter should be determined based on historical data for the given water system. If this information is not available, it can be estimated based on the Langelier Index or extrapolated from other utilities with similar water quality.

47. Since the C-factor is a logarithmic function of time, the C-factor tends to decrease most rapidly for new or recently cleaned pipes. However, after a few decades the drop in C-factor with time is very slow. 
California Section AWWA Committee. 1962(Oct). "Loss of Carrying Capacity in Water Mains," J. AWWA, Vo1. 54, No. 10, p. 1293.

Colebrook, C. F. 1939. "Turbulent Flow in Plpes with Particular Reference to the Transition Region between the Smooth and Rough Pipe Laws," J. Inst. Civil Eng. London, Vol. 11, p. 133.

Colebrook, C. F., and C. M. White. 1937. "The Reduction of Carrying Capacity of Pipes with Age," J. Inst. Civil Eng. London, Vol. 10, p. 99.

Costello, J. J. 1982. "Postprecipitation in Distribution Lines Following Water Treatment, National Conf Proceedings, p. 1245.

Dutting, R. F. 1968. "Cleaning and Lining Water Mains in Place," presented at New England Water Works Association Training School.

Emery, P. M. 1980. "Some Aspects of the Performance of Cement Mortar Lined Water Mains," AWWA Nat1. Conf. Proceedings, p. 249.

Frank, J. A., and Perkins, A. G. 1955(Apr). "Water Main Cleaning and LinIng," Water and Sewage Works.

Hudson, W. D. 1966(Feb). "Studies of Distribution System Capacity in Seven Cities," J. AWWA, Vol. 58, No. 2.

Hudson, W. D. 1966(Apr). "Loss of Water Main Capactty," J. Southeastern Sec. AWWA, Vol. 30 , No. 1, p. 44.

Hudson, W. D. 1973(Feb). "Computerizing Pipeline Design," ASCE Transportation Engineering Journal, Vo1. 99, No. TE1, p. 73.

Lamont, P. A. 1981 (May). "Common Plpe Flow Formulas Compared with the Theory of Roughness," J. AWWA, Vol. 73, No. 5, p. 274.

Larson, T. E., and Sollo, F. W. 1967 (Dec). "Loss in Water Main Carrying Capacity," J. AWWA, Vol 59, No. 12, p. 1565.

New England Water Works Association Committee on Pipeline Friction Coefflctents. 1935. "Summary of Report," J. New England Water Works Assoclation, Vol 49, p. 239.

Nikuradse, J. 1932. "Gesetzmassigkeiten der Turbulenten Stromung in Glatten Rohren," VDI Forschungsh, Vol. 356.

Ormsbee, L. E., and Wood, D. J. 1986 (Apr). "Explicit Pipe Network Calibration," J. of Water Resources Planning and Management, Vol. 112, No, 2, p. 166.

Prandt1, L. 1933. "Neuere Ergebnisse der Turbulenxforschung," Zeft. Ver. deu. Ing., Vol. 77 , p. 105.

Streeter, V. L. 1971. Fluld Mechanics, McGraw-H111, Inc., New York.

Swamee, P. K., and Jain, A. K. 1976(May). "Explicit Equations for Pipe-Flow Problems," ASCE Journal of Hydraulics Division, Vo1. 102, No. HY5, p. 657.

von Karman, T. 1930. "Mechanisehe Ahnlichkeit und Turbulenz," Proc. 3rd International Congress for Applied Mechanics, Stockholm.

Walsk1, T. M. 1984. Analysis of Water Distribution Systems, Van Nostrand Reinhold, Inc., New York. 
Walski, T. M. 1986(Apr). "Case Study: Pipe Network Model Calibration Issues," J. of Water Resources Planning and Management, Vo1 112, No. 2, p. 238 .

Williams, G. S., and Hazen, A. 1920. Hydraulic Tables, John Wiley \& Sons, New York. 